\section{Autologous blood donation in support of cardiac surgery: a preliminary report on a hospital-based autologous donor programme}

P.H. Pinkerton MD FRCPC
The purpose of this study was to assess the success or otherwise of the introduction of an autologous blood programme in support of cardiac surgery in reducing patient exposure to allogeneic blood products and to assess the guideline of two units as the collection schedule for such patients. Sixty-six patients were enrolled in the programme provided they met defined clinical conditions and donated one, two or three units of blood at seven-day intervals, using isovolaemic conditions. One minor vasovagal adverse reaction was recorded. Of the 66 patients, 51 (77\%) avoided allogeneic red cells and $42(64 \%)$ received no allogeneic product. If each patient deposited two units, 51 (77\%) would have required no allogeneic red cells; if three units were deposited, 57 (86\%) patients would have required no allogeneic red cells, but 60 units would be surphs to requirements. Comparison of 52 patients for coronary artery bypass grafiing who were autologous donors, with 130 patients undergoing the procedure before the availability of autologous blood, supports the suggestions that there is increased readiness to initiate transfusion of autologous blood and that exposure to allogeneic red cells is reduced. However, exposure to allogeneic products of all kinds is not reduced. It is concluded that the collection of two units of autologous blood is appropriate for most eligible

\section{Key words}

BLOOD: tranfusion, autologous;

SURGERY: cardiac;

TRANSFUSION: autologous blood.

From the Department of Laboratory Haematology,

Sunnybrook Health Science Centre, Toronto, Ontario, Canada.

Address correspondence to: Dr. P.H. Pinkerton, Department of Laboratory Haematology, Sunnybrook Health Science

Centre, 2075 Bayview Avenue, Toronto, Ontario M4N 3M5,

Canada.

Accepted for publication 3rd June, 1994. patients and that this reduces exposure to allogeneic red cells. However, the failure to influence allogeneic blood product exposure implies that if autologous blood donation for this group of patients is to contribute to reduced patient exposure to allogeneic donors, critical appraisal of the need for transfusion of blood components other than red cells will be required.

Cette étude vise à évaluer les résultats de la mise en opération d'un projet d'administration de sang autologue en chirurgie cardiaque. Ce programme a été implanté dans le but de diminuer le contact aux produits sanguins allogéniques et d'évaluer le bien-fondé de la collecte de deux unités de sang en chirurgie cardiaque. Soixante-six patients ont été recrutés pour ce projet. Ils devaient rencontrer certaines conditions cliniques et avaient déjà offert une, deux ou trois unités de sang à sept jours d'intervalle avec maintien de lisovolémie. Une réaction mineure vasovagale a été enregistrée. Chez ces 66 patients, 51 (77\%) ont évité les transfusions d'hématies allogéniques et 42 (64\%) n'ont reçu aucun autre produit sanguin allogénique. Si chaque patient avait fait un dépôt de deux unités, 51 (77\%) n'auraient eu pas besoin d'hématies allogéniques; avec un dépôt de trois unités, 57 (86\%) des patients n'auraient pas eu besoin d'hématies allogéniques mais 60 unités auraient été recueillies en surplus. La comparaison de 52 donneurs autologues soumis à une chirurgie de dérivation coronarienne avec 130 patients soumis à la même chirurgie avant la mise en marche du projet supporte la notion que linitiation de transfusions autologues gagne du terrain et que l'exposition à des hématies allogéniques diminue. Cependant, l'exposition à des produits allogéniques de toutes provenances demeure la même. En conclusion, la cueillette de deux unités de sang autologue est appropriée pour la plupart des patients éligibles, ce qui réduit l'exposition aux hématies allogéniques. Cependant, l'incapacité dinfluer sur l'exposition aux autres produits sanguins allogéniques signifie que si la cueillette de sang autologue pour ce groupe de patients devait contribuer à diminuer l'exposition à des donneurs allogéniques, 
il faut maintenant évaluer plus précisément les besoins de transfusions de produits sanguins autres que les hématies.

In the last few years, there has been an increasing interest in the use of autologous blood for support of elective surgery, mainly as a result of increasing concerns about transmissible disease, but also because of evidence to indicate immunosuppressive effects of allogeneic transfusion and the possibility of increased liability to postsurgical infection or recurrence of malignant disease. ${ }^{1-4}$ In some centres, a considerable contribution to the total blood supply is derived from autologous donation.

For cardiac surgery, ${ }^{5-7}$ the use of pre-deposited autologous donor blood has been shown to be effective in reducing exposure to and dependence on allogeneic blood. Furthermore, collection of blood from donors with cardiovascular disease does not appear to be accompanied by an increased frequency of adverse reactions. ${ }^{5-7}$

Autologous donor programmes are more readily accessible to patients in the United States than in Canada, where the blood collection system does not readily provide for appropriate medical supervision at donor clinics and patients with cardiovascular disease are generally excluded. Without the tradition of hospital-based blood donor clinics as in the United States, Canadian hospitals have been unwilling or unable to find the resources to mount widely available systematic autologous blood donor clinics. In June 1991, such a service was instituted here and, since September 1991, has accepted patients for cardiac surgery. 8,9

This paper describes our experience from initiation of the programme until December 31st, 1993 in respect of 66 patients undergoing cardiac surgery, during which period a total of 680 patients were enrolled as autologous donors in preparation for a variety of elective surgical procedures. ${ }^{9}$ A total of 1478 cardiac surgical procedures was carried out here in the same period.

\section{Methods}

Patients are provided with an information brochure and, having selected this option, are referred to the programme by the attending surgeon. Patients are required to meet certain criteria for fitness to donate ${ }^{8,9}$ which are similar to those in wide use in centres in the United States and are described in detail elsewhere. ${ }^{8,9}$ Cardiovascular exclusion criteria include blood pressure (systolic $<90$ $\mathrm{mmHg}$ or $>200 \mathrm{mmHg}$, diastolic $<50 \mathrm{mmHg}$ or $>110$ $\mathrm{mmHg}$ ), unstable angina pectoris, severe stenotic heart valve disease, left main coronary artery insufficiency, cerebrovascular disease (previous stroke or transient ischaemic attacks) and congestive cardiac failure. Donations are generally scheduled at weekly intervals with the last donation no less than $72 \mathrm{hr}$ before surgery. Patients' general health is assessed by the donor room nursing staff according to a standard protocol and any questions requiring medical assessment are referred to medical staff on call. Blood is collected from patients for cardiac surgery using an isovolaemic technique with $500 \mathrm{ml}$ normal saline. A database has been compiled which includes information on the amount of blood requested, collected and used, the nature of the surgical procedure conducted, the use of allogeneic products (supplied by the Canadian Red Cross Society's Blood Transfusion Service) and adverse reactions.

The actual use of blood and products, both autologous and allogeneic, is confirmed in the blood bank computer system (Hemocare $\left.{ }^{(}\right)$, where the use of each unit of product issued has been verified within one working day of transfusion. The amount of blood collected is generally two units, although occasionally more or less may be obtained depending on the number requested by the surgeon, the time available before surgery and the condition of the patient. Of our 66 patients, 44 donated the usual number of two units, 15 donated one unit and for the remaining seven patients, three units were obtained. Eight patients were deferred from further donation after depositing one or more requested units because of intercurrent infection (usually upper respiratory tract) or poor venous access. Several patients donated fewer than the requested number of units because insufficient time was available between enrollment in the donor programme and scheduled surgery. One of the 66 patients suffered a minor vaso-vagal reaction at the end of the second donation. No other adverse effect has been noted.

Of the 66 patients, 52 underwent coronary artery bypass grafting and the remainder underwent a variety of procedures.

The term "wastage" is used to identify blood collected and not used, and "avoidance" to indicate absence of exposure to allogeneic blood products including packed red blood cells (PRBC), platelets, plasma and cryoprecipitate.

Blood and blood product consumption from 130 consecutive patients undergoing coronary artery bypass graft (CABG) before the introduction of the autologous programme has also been obtained from the Hemocare ${ }^{\circledR}$ database and is compared with the 52 patients in the autologous programme who underwent CABG. This comparison was undertaken with the recognition that the historical nature of these controls and differences in case selection require caution in interpretation of differences.

\section{Results}

For 66 patients, 125 units were collected and 94 (75\%) were used (Table I). Fifteen of the 66 patients enrolled 
TABLE I Collection and use of units of autologous blood and use of units of allogeneic packed red blood cells (PRBC) for cardiac surgery in 66 patients

\begin{tabular}{llll}
\hline & \multicolumn{2}{l}{ Blood/Red cells } & \\
\cline { 2 - 3 } & \multicolumn{2}{l}{ Autologous } & \\
\cline { 2 - 3 } Procedure & $\begin{array}{l}\text { Collected } \\
(n)\end{array}$ & $\begin{array}{l}\text { Used } \\
(n)\end{array}$ & $\begin{array}{l}\text { Allogeneic } \\
(n)\end{array}$ \\
\hline $\begin{array}{llll}\text { Coronary artery bypass graft } \\
\text { (CABG) }\end{array}$ & 96 & 76 & 25 \\
Other & $(52)$ & $(47)$ & $(13)$ \\
Total & 29 & 18 & 7 \\
& $\frac{(14)}{(25}$ & $\frac{(10)}{94}$ & $\frac{(2)}{32}$ \\
& $(66)$ & $(57)$ & $(15)$ \\
\hline
\end{tabular}

*(n): number of patients.

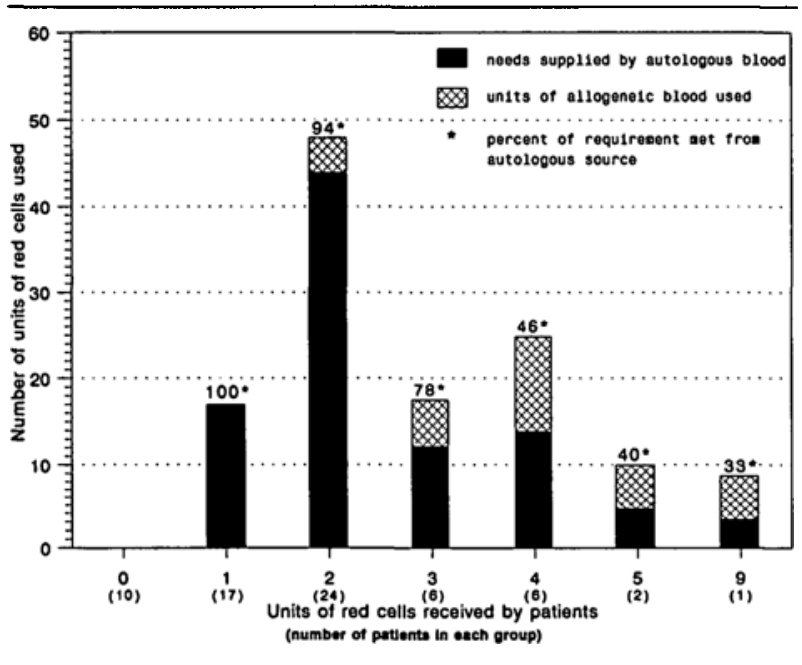

FIGURE 1 Use of red cells by 66 patients enrolled in the autologous blood donor programme undergoing cardiac surgery.

in the programme received one or more units of allogeneic PRBC and 51 (77\%) avoided the use of allogeneic PRBC. There was "wastage" of $25 \%$ of the units collected. The ability of autologous donations to meet the requirements for red cell transfusion are illustrated in Figure 1 . Fifteen patients predeposited one unit, 44 predeposited two units and seven deposited three units.

Data not provided in the Table or Figure indicate that had two units been collected from each patient, 51 (77\%) of patients would have avoided allogeneic PRBC (the same number as was seen in practice) and that had three units been collected from each patient 57 (86\%). would have avoided allogeneic PRBC but there would have been additional wastage of 60 units, assuming the same transfusion decisions had been made.

In Table II, the use of allogeneic products other than
TABLE II Use of blood products other than red cells by 66 patients enrolled in the autologous blood programme and undergoing cardiac surgery

\begin{tabular}{|c|c|c|}
\hline \multirow[b]{2}{*}{$\begin{array}{l}\text { Blood product } \\
\text { used }\end{array}$} & \multicolumn{2}{|l|}{ Red cell product used } \\
\hline & $\begin{array}{l}\text { Autologous only } \\
\text { or none }\end{array}$ & $\begin{array}{l}\text { Autologous } \\
\text { plus allogeneic }\end{array}$ \\
\hline Platelets* & $5,5,5,6,6,6,6(7) \dagger$ & $\begin{array}{l}\text { It, } 3,5,6,6,6,12,12 \text {, } \\
12,18(9) \dagger\end{array}$ \\
\hline Plasma§ & $2,4,(2) \dagger$ & $2,2,2,3,4(5) \dagger$ \\
\hline Cryoprecipitate* & $8(1) \dagger$ & $8,8,8,8(4) \dagger$ \\
\hline
\end{tabular}

* Number of donors for each product supplied.

$\dagger(n)$ : number of patients in group.

$\ddagger$ A single apheresis platelet product.

\$Number of units used.

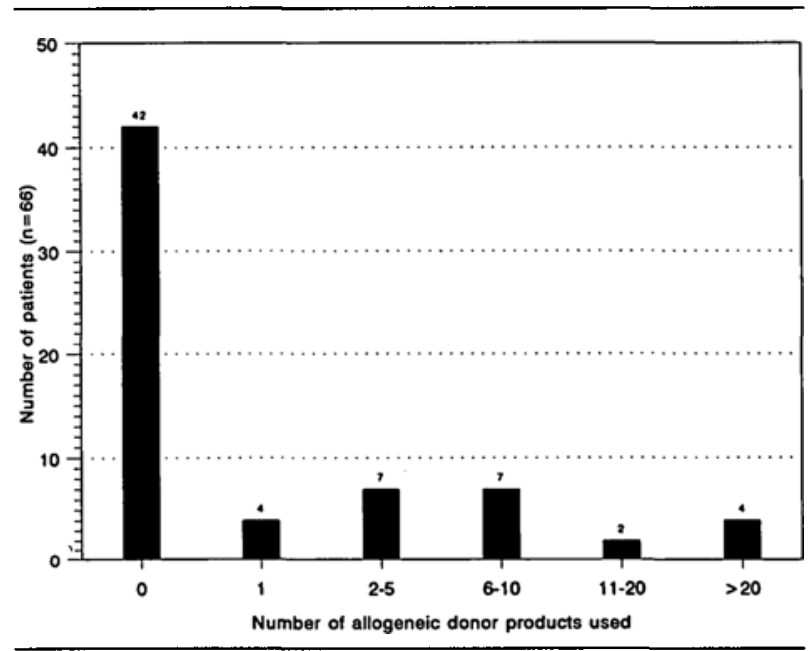

FIGURE 2 Exposure to allogeneic blood products of 66 patients enrolled in the autologous blood donor programme who underwent cardiac surgery with cardiopulmonary bypass. The number of patients in each group is noted at the top of the columns.

PRBC is presented, divided into two categories; those receiving no allogeneic PRBC, and those receiving both autologous blood and allogeneic PRBC. Further analysis indicates that of the 66 patients in the study, $42(64 \%)$ received no allogeneic product, seven (11\%) received allogeneic PRBC, eight (12\%) received allogeneic PRBC and other product, and nine (14\%) receive no allogeneic PRBC but did receive other allogeneic product.

The total exposure to allogeneic products is summarized in Figure 2.

Comparison of exposure to allogeneic products of 52 autologous donors and 130 patients not pre-depositing their own blood is presented in Table III. Sixty-three of the latter received no transfusion at all compared with six of the 52 autologous donors; thirty-two of the 52 autologous donors received no allogeneic product compared 
TABLE III Autologous donors and non-donors compared in respect of those receiving no transfusion and those receiving no allogeneic product

\begin{tabular}{|c|c|c|c|}
\hline Patients & $\begin{array}{l}\text { Number } \\
\text { receiving no } \\
\text { transfusion }\end{array}$ & $\begin{array}{l}\text { Number } \\
\text { receiving no } \\
\text { allogeneic } \\
\text { product }\end{array}$ & $\begin{array}{l}\text { Number } \\
\text { receiving no } \\
\text { allogeneic } \\
\text { red cells }\end{array}$ \\
\hline $\begin{array}{l}\text { Autologous donors } \\
\text { (52) }\end{array}$ & 6 & 32 & 39 \\
\hline $\begin{array}{l}\text { Autologous non-donors } \\
\text { (130) }\end{array}$ & 63 & 63 & 69 \\
\hline$P \dagger$ & $<0.00001$ & $>0.05$ & $<0.02$ \\
\hline
\end{tabular}

*(n): total number of patients in the group.

+Calculated using Chi-square test with Yates correction

with 63 of 130 non-donors. Finally, 39 of $52(75 \%)$ autologous donors received no allogeneic red cells compared with 69 of $130(53 \%)$ of non donors.

\section{Discussion}

Sixty-six patients of a total of 1478 undergoing cardiac surgery between September 1, 1991 and December 31, 1993 enrolled in an autologous blood donor programme for pre-surgical deposit. The use of this programme is based on the patients' option to choose autologous blood support for their surgery, their fitness to participate based on defined clinical criteria, ${ }^{8,9}$ and sufficient time to collect blood before surgery.

There is wide variability in the use of blood and blood products in support of cardiac surgery. Thus, Goodnough et al., ${ }^{10}$ in assessing data from 18 hospitals, found that the mean red cell use in first-time coronary artery bypass graft surgery (CABG) varied from 0.4 to 6.3 units per case. In six hospitals, more than $50 \%$ of patients received plasma, whereas in nine hospitals, less than $20 \%$ received plasma. Similarly, four of 18 centres used platelets for $50 \%$ or more of patients and eight out of 18 used platelets in $10 \%$ or less. Only three hospitals at the time of the surgery provided autologous blood donor programmes. These results clearly indicated a need for the review of policies regarding blood and blood product use.

Autologous blood support represents one means of reducing exposure of patients to allogeneic blood products, and programmes have been successfully and safely introduced elsewhere ${ }^{5-7}$ with minimal adverse effects of donation, as has been noted here. Thus, Love et al. ${ }^{5}$ reduced allogeneic red cell exposure from $62 \%$ to $36 \%$ with an average donation of 1.97 units of autologous blood (using an average of 1.7 units) with little difference in the use of other products. In another study, ${ }^{6} 77$ of 102 patients donating a mean of 4.1 units autologous blood avoided use of allogeneic blood, compared with 23 of 110 patients not participating in the autologous programme. Finally,
Owings et al. ${ }^{7}$ reduced allogeneic red cell exposure from $82 \%$ of patients to $27 \%$ (i.e., an avoidance rate of $73 \%$ ) by introduction of an autologous blood donor programme.

In the present study, the cohort of 66 patients enrolled in this programme has achieved $77 \%$ avoidance of allogeneic red cell transfusion, with only one patient experiencing an adverse effect of donation, an experience which is similar to other studies. ${ }^{11,12}$ The data presented here would also seem to confirm the appropriateness of a schedule of two units of autologous blood for most patients undergoing cardiac by-pass surgery, as the collection of an additional unit per patient would result in substantial wastage with little additional benefit.

The use of non-red cell allogeneic products compromises the purpose and integrity of the concept of autologous blood support for surgery, providing additional allogeneic donor exposure. This is particularly evident in the use of platelets and cryoprecipitate which are usually made available for transfusion in multi-donor packs. Cardiovascular surgery has traditionally used large amounts of such support and has been a major consumer of platelets in the past, ${ }^{13,14}$. even though evidence of need in the form of thrombocytopenia was frequently lacking. ${ }^{14}$ The observations of Goodnough et al. ${ }^{10}$ on the heterogeneity of practice in 18 hospitals support the need for careful evaluation of prophylactic therapy, and an algorithm for decisions regarding blood component use has been proposed. ${ }^{15}$

In the comparison of 130 patients undergoing CABG without predeposit and 52 autologous donors undergoing $\mathrm{CABG}$, it appears that autologous donors received transfusion more frequently than the "control" population. Further, although the 52 autologous donors showed improved avoidance of allogeneic red cell transfusion (from 53\% to $75 \%$ ), the difference in exposure to allogeneic blood products of all kinds was not different. These conclusions must be interpreted with caution due to the historical and unmatched nature of the controls. Nevertheless, they support the suggestion that blood component use is a consideration in determining the appropriateness of autologous blood programmes for this group of patients. Further, they support the idea that there is less reluctance to initiate transfusion with autologous than allogeneic red cells in association with surgery.

If autologous blood programmes are to have an impact on patient exposure to allogeneic donations (as opposed simply to supplementing the blood supply), critical appraisal of the need to transfuse blood products will be essential in every patient.

\section{Aknowledgements}

I am grateful to A.S. Coovadia and J. Young for their 
major contributions to the establishment and operation of the autologous donor programme. I am also indebted to D. Dawkins and C. Yrfelt for careful maintenance of the database and to A. Giesta for preparation of the manuscript.

\section{References}

1 Blumberg $N$, Heal JM. Perioperative blood transfusion and solid tumour recurrence. Blood Rev 1987; 1: 219-29.

2 Chambers LA, Kruskall MS. Preoperative autologous blood donation. Transfus Med Rev 1990; 4: 35-46.

3 Triulzi DJ, Blumberg N, Heal JM. Association of transfusion with postoperative bacterial infection. Crit Rev Clin Lab Sci 1990; 28: 95-107.

4 Perkins HA. Autologous transfusions. Adv Intern Med 1990; 35: 221-33.

5 Love TR, Hendren WG, O'Keefe DD, Daggett WM. Transfusion of predonated autologous blood in elective cardiac surgery. Ann Thorac Surg 1987; 43: 508-12.

6 Britton LW, Eastlund DT, Dziuban SW, et al. Predonated autologous blood use in elective cardiac surgery. Ann Thorac Surg 1989; 47: 529-32.

7 Owings DV, Kruskall MS, Thurer RL, Donovan LM. Autologous blood donations prior to elective cardiac surgery. Safety and effect on subsequent blood use. JAMA 1989; 262: 1963-8.

8 Pinkerton PH, Young J, Coovadia AS. A hospital based program for pre-surgical deposit of autologous blood. Bulletin of the Canadian Society of Transfusion Medicine 1993; 5: 49-55.

9 Pinkerton PH. Two years experience with a Canadian hospital-based autologous blood donor programme. Transfusion Medicine (in press).

10 Goodnough LT, Johnston MFM, Toy PTCY, et al. The variability of transfusion practice in coronary artery bypass surgery. JAMA 1991; 265: 86-90.

11 Mann M, Sacks HJ, Goldfinger D. Safety of autologous blood donation prior to elective surgery for a variety of potentially "high-risk" patients. Transfusion 1983; 23: 229-32.

12 McVay PA, Andrews A, Kaplan EB, et al. Donation reactions among autologous donors. Transfusion 1990; 30: 249-52.

13 Menitove JE, McElligott MC, Aster RH. Where have all the platelets gone? - a strategy for monitoring platelet usage. Wis Med J 1982; 81: 11-3.

14 Silver SS, Rock G, Décary F, et al. Use of platelet concentrate in eastern Ontario. Can Med Assoc J 1987; 137: 128-32.

15 Goodnough LT, Johnston MFM, Ramsey G, et al. Guidelines for transfusion support in patients undergoing coronary artery bypass grafting. Ann Thorac Surg 1990; 50: $675-83$ 